OPEN ACCESS

Edited by:

Yuanyuan Feng,

Tianjin University of Science and

Technology, China

Reviewed by:

Peng Jin,

University of Guangzhou, China

Yuyuan Xie,

Northeast Fisheries Science Center

(NOAA), United States

${ }^{*}$ Correspondence:

Xingyu Song

songxy@scsio.ac.cn

Gang Li

ligang@scsio.ac.cn

Specialty section:

This article was submitted to Global Change and the Future Ocean,

a section of the journal

Frontiers in Marine Science

Received: 17 May 2021

Accepted: 21 June 2021

Published: 16 July 2021

Citation:

Mai G, Liu J, Xia X, Pang X, Li B, Yu L,

Tan Y, Song X and Li G (2021) Acutely

Rising Temperature Reduces

Photosynthetic Capacity of

Phytoplankton Assemblages in

Tropical Oceans: A Large-Scale

Investigation

Front. Mar. Sci. 8:710697.

doi: 10.3389/fmars.2021.710697

\section{Acutely Rising Temperature Reduces Photosynthetic Capacity of Phytoplankton Assemblages in Tropical Oceans: A Large-Scale Investigation}

\author{
Guangming Mai ${ }^{1,2,3}$, Jihua Liu ${ }^{4}$, Xiaomin Xia ${ }^{1,2,3}$, Xinyue Pang ${ }^{4}$, Binkai $\mathrm{Li}^{5}$, Linghui Yu${ }^{6}$, \\ Yehui Tan ${ }^{1,2,3}$, Xingyu Song ${ }^{1,2,3,7 *}$ and Gang $\mathrm{Li}^{1,2,3 *}$
}

\begin{abstract}
${ }^{1}$ Key Laboratory of Tropical Marine Bio-Resources and Ecology, South China Sea Institute of Oceanology, Chinese Academy of Sciences, Guangzhou, China, ${ }^{2}$ Southern Marine Science and Engineering Guangdong Laboratory (Guangzhou), Guangzhou, China, ${ }^{3}$ University of Chinese Academy of Sciences, Beijing, China, ${ }^{4}$ Institute of Marine Science and Technology, Shandong University, Qingdao, China, ${ }^{5}$ Qinghai Institute of Salt Lakes, Chinese Academy of Sciences, Xining, China, ${ }^{6}$ State Key Laboratory of Tropical Oceanography, South China Sea Institute of Oceanology, Chinese Academy of Sciences, Guangzhou, China, ${ }^{7}$ Nansha Marne Ecological and Environmental Research Station, South China Sea Institute of Oceanology, Chinese Academy of Sciences, Guangzhou, China
\end{abstract}

Climate changes interacting with human activities are raising the temperature in global oceans. To explore physiological responses of in situ phytoplankton assemblages to increasing temperatures, we conducted a shipboard experiment in tropical regions of the eastern Indian Ocean, Java Sea, and southern South China Sea. Throughout the surveyed areas, phytoplankton biomass (Chla) ranged from 0.09 to $0.86 \mu \mathrm{g} \mathrm{L}^{-1}$ (median, $0.22 \mu \mathrm{g} \mathrm{L}^{-1}$ ) in the surface and from 0.30 to $0.99 \mu \mathrm{g} \mathrm{L}^{-1}$ (median, $0.50 \mu \mathrm{g} \mathrm{L}^{-1}$ ) in maximal chlorophyll layer (DCM), respectively. Picophytoplankton that occupied 27-89\% (79\%) and 83-92\% (88\%) of total Chla in the surface and DCM layers, ranged from 0.32 $\times 10^{4}$ to $23.10 \times 10^{4}$ cells $\mathrm{mL}^{-1}\left(3.69 \times 10^{4}\right.$ cells $\left.\mathrm{mL}^{-1}\right)$ and from $7.44 \times 10^{4}$ to $25.70 \times 10^{4}$ cells $\mathrm{mL}^{-1}\left(12.60 \times 10^{4}\right.$ cells $\left.\mathrm{mL}^{-1}\right)$, respectively. Synechococcus took up $30-97 \%(78 \%)$ of pico-cells compositions in the surface layer, while, in the DCM layer, Prochlorococcus took up 42-98\% (91\%). Moreover, the maximal photochemical quantum yield ( $\left.\mathrm{FV}_{\mathrm{V}} / \mathrm{F}_{\mathrm{M}}\right)$ of photosystem II (PS II) and the rapid light curve (RLC)-derived light utilization efficiency $(\alpha)$ were lower in the surface layer than that in the DCM layer, but the saturation irradiance $\left(E_{K}\right)$ was higher. In particular, we found that acutely rising temperature decreased the $\mathrm{F}_{\mathrm{V}} / \mathrm{F}_{\mathrm{M}}$ and $\alpha$ in both the surface and the DCM layers but increased the absorption cross-section ( $\sigma_{\mathrm{PSII}}$ ) of PSII photochemistry. Our results clearly indicate that the presently rising temperature adversely affects the photophysiology of natural phytoplankton assemblages in tropical oceans.

Keywords: rising temperature, photosynthetic performance, phytoplankton assemblages, community structure, tropical oceans 


\section{INTRODUCTION}

Marine phytoplankton, a group of single-cell organisms (Pachiappan et al., 2019), are the major primary producers in aquatic ecosystems. They contribute to about half of a global carbon fixation (Field et al., 1998) and are thus considered to play an important role in mitigating the effects caused by excessive atmospheric $\mathrm{CO}_{2}$ by photosynthesis (Cavicchioli et al., 2019; Buesseler et al., 2020). The photosynthesis of phytoplankton is regulated by numerous environmental variables, such as solar UV radiation, temperature, and mixing, etc. (Gao et al., 2019; Jin et al., 2019), among which the temperature is a particularly important factor (Jin and Agustí, 2018). This is because the varying temperature can alter enzymes activities within cells, regulate their physiological metabolisms, and ultimately affect photosynthesis and growth (Gao et al., 2019). Rising temperature is often detected to enhance the activities of photosynthetic-involved enzymes of phytoplankton, like the Ribulose-1,5-bisphosphate carboxylase-oxygenase (RubisCO), thus leading to the promotion of photosynthetic oxygen production and carbon fixation (Li et al., 1984; Young et al., 2015). Such an increased temperature was also observed to compensate for the negative effects of other stressors like high light (Bouterfas et al., 2002) or UV-B radiation (Jin et al., 2019) upon photosynthesis. Therefore, the phytoplankton growth is often stimulated by increased temperature, such as for diatoms Chaetoceros tenuissimus and Synedra sp. (Jin and Agustí, 2018) or coccolithophore Emiliania huxleyi (Schlüter et al., 2014).

Owing to over-emissions of anthropogenic $\mathrm{CO}_{2}$, global warming has accelerated since the industrial revolution (IPCC, 2013). In the global climate system, over $90 \%$ of the excess heat gained by the planet has been taken up by the oceans (von Schuckmann et al., 2020), enabling surface seawater temperature to rise up to $4^{\circ} \mathrm{C}$ by the end of this century (IPCC, 2013; Tokarska et al., 2020); the ocean-absorbed heat energy has been reported to penetrate even to $700 \mathrm{~m}$ (von Schuckmann et al., 2020). Meanwhile, the frequency and the intensity of marine heatwaves, the regional extreme warming in surface oceans (Hobday et al., 2016), have also increased in the global warming scenario (Oliver et al., 2018). The marine heat wave-induced increase of temperature has been recorded over $6^{\circ} \mathrm{C}$ in the South Island of the New Zealand during the austral hot summer of 2017/18, largely lowering the coverage of Durvillaea poha and varying local algal diversity (Thomsen et al., 2019). Such a temperature increase has also been detected to reduce nearly $50 \%$ of phytoplankton biomass and shift more than $50 \%$ of micro-cells to smaller ones $(<5 \mu \mathrm{m})$ in the Pacific Northwest (Kosro et al., 2006; Kudela et al., 2006). On the other hand, the increasing temperature-activated diatoms blooms have also been observed for, e.g., Chaetoceros coarctatus in the south coast of the southern Australia during the austral summer 2013 (Roberts et al., 2019) and Pseudo-nitzschia australis along the western coast of the North America in April of 2015 (Gentemann et al., 2017; Trainer et al., 2020), as well as polar diatoms around the Antarctic region (Montie et al., 2020). To fully understand the underlying mechanisms, it is necessary to explore how phytoplankton physiologically responds to the increased temperature.
The Indian Ocean, Java Sea, and the southern South China Sea are geographically located in the center of the Indo-Pacific warm pool, the warm surface region of the world (Weller et al., 2016), wherein surface temperature generally maintains over $28^{\circ} \mathrm{C}$ throughout the year (De Deckker, 2016). In the global warming scenario, these tropical regions, being no exception, are subjected to the increased temperature (De Deckker, 2016; Weller et al., 2016), leading to a morphological shrink in cell size of phytoplankton (Mousing et al., 2014) and reduction in biomass (Roxy et al., 2016; Zhang et al., 2018). Using an ecological model study, Roxy et al. (2016) reported that the increased temperature had reduced over 20\% phytoplankton biomass in the Indian Ocean from 1950 to 2012. With the shipboard experiments, Zhang et al. (2018) found that the increased temperature declined roughly $50 \%$ of surface biomass in the southern South China Sea in the summer period of 2017. To date, however, few studies on photosynthetic behaviors of natural phytoplankton assemblages in response to ocean warming have been conducted in these tropical regions. As ambient temperatures in these regions are high, close to or even over the optimal growth temperature of phytoplankton (Jin and Agustí, 2018), we, thus, hypothesized that further elevated temperature would be detrimental to phytoplankton in these regions. However, it is not practicable, although of significance, to launch a large-spatial and long-term incubation experiment to examine phytoplankton responses to rising temperature. Therefore, we investigated the photophysiological responses to acutely elevated temperature of phytoplankton assemblages from the surface or/and the maximal chlorophyll layer (DCM) of the eastern Indian Ocean, Java Sea, and southern South China Sea (Figure 1). Our results clarified how the increased temperature affects the photosynthetic performance of phytoplankton assemblages in the spatial and depth scales; it would be helpful for understanding the ecological effects of rising temperature in these tropical oceans.

\section{MATERIALS AND METHODS \\ A Study Area and Sampling Protocol}

During a cruise from September 21 to November 16, 2020, this experiment was conducted on board of R/V Shiyan 3 in the tropical oceans (i.e., eastern Indian Ocean, southern South China Sea, and Java Sea, and their connecting passages) (Figure 1). The seawater samples were collected from two depth layers: surface $(\sim 1$-m depth) being taken with a clean pump system and that from the DCM layer being taken with an 8- L Niskin bottle mounted on an SBE 911 plus CTD (SeaBird Electronics, Inc., Bellevue, WA, USA). The DCM layer was determined, using a chlorophyll fluorometer equipped with CTD. To eliminate the effects of diel rhythm of phytoplankton photosynthetic activity (Xie et al., 2018), all the seawater samples were taken in the daytime ( 9 a.m. to 2 p.m.). During the cruise, the seawater temperature and salinity were measured with thermosalinographs (a shipboard CTD) and Sea-Bird CTD.

\section{Experimental Design}

To investigate the effects of acutely rising temperature upon the physiology of natural phytoplankton assemblages, the collected 


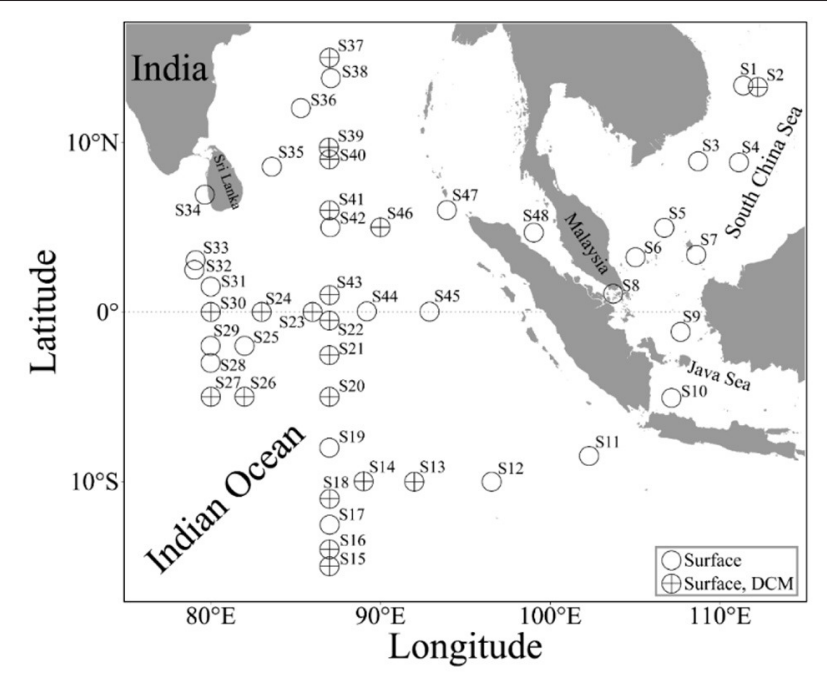

FIGURE 1 | Sampling sites in the eastern Indian Ocean, Java Sea, and southern South China Sea. O, the seawater was taken from the surface alone; $\bigoplus$, the seawater was taken from both the surface and maximal chlorophyll layers (DCM). seawater samples from the surface or/and the DCM layers of each station were used to measure photosynthetic performance, using a fast repetition rate fluorometer (FRRf, Chelsea Technologies Group, Ltd., West Molesey, UK) under four or five different temperatures. To improve the signal-to-noise ratio of chlorophyll fluorescence of phytoplankton assemblages, 2-L seawater was concentrated to $\sim 100 \mathrm{ml}$ by gently filtrating with a $0.45-\mu \mathrm{m}$ pore-sized nitrocellulose membrane ( $25 \mathrm{~mm}$, Millipore) within $10 \mathrm{~min}$ after being taken from in situ conditions. Then, the concentrated sample was quickly injected into a $10-\mathrm{mL}$ chamber of FRRf that was encircled by a water jacket connected to a circulating thermostatted bath to maintain temperature and dark acclimated for $10 \mathrm{~min}$, followed by measuring chlorophyll fluorescence with the FRRf at in situ temperature. After this, the temperature in a $10-\mathrm{mL}$ chamber was acutely increased by $3^{\circ} \mathrm{C}$ and maintained for $10 \mathrm{~min}$, and the fluorescence was measured again. The fluorescence of phytoplankton from the surface at each station was sequentially measured under in situ temperature, $+3,+6$, and $+9^{\circ} \mathrm{C}$, and that from the DCM layer was measured under in situ temperature, surface, $+3,+6$, and $+9^{\circ} \mathrm{C}$. After measuring the fluorescence for one step, we mixed the sample by turning on the mixing button of FRRf to eliminate the effect of the settlement. According to the RCP 8.5 scenariooriented projection (IPCC 2013), surface seawater temperature would rise by $4^{\circ} \mathrm{C}$ at the end of 2100 ; however, such a temperature increase could be over $6^{\circ} \mathrm{C}$ due to marine heatwaves (Thomsen et al., 2019). So, we set a maximal increase of $9^{\circ} \mathrm{C}$ in this study.

\section{FRRf Measurement}

Under each temperature, the FRRf measurement was operated with a light response protocol, i.e., an initial 60-s dark step, followed by nine actinic lights that were supplied by a panel of blue LEDs at a wavelength centered on $450 \mathrm{~nm}$ in the FastAct
(Wei et al., 2019b). The actinic light levels varied from 0 to 1,500$\mu \mathrm{mol}$ photons $\mathrm{m}^{-2} \mathrm{~s}^{-1}$, with each step lasting $60 \mathrm{~s}$, except for the first step that lasted $120 \mathrm{~s}$ with the low light of $\sim 15-\mu \mathrm{mol}$ photons $\mathrm{m}^{-2} \mathrm{~s}^{-1}$ to eliminate the effect of light history signals on the measured variable fluorescence (From et al., 2014). The fluorescence light curve (FLC) was measured, following Hughes et al. (2018a,b) by setting FRRf with a single turnover induction protocol, i.e., a train of $100 \times 2-\mu$ s flashlets of blue light $(450 \mathrm{~nm})$ at an interval of $2.8 \mu$ s (Song et al., 2019). The minimal and maximal fluorescence in the dark $\left(\mathrm{F}_{\mathrm{O}}, \mathrm{F}_{\mathrm{M}}\right)$ and in light state $(F$, $\left.F_{M}^{\prime}\right)$ and the absorption cross-section of photosystem II (PSII) photochemistry $\left(\sigma_{P S I I}, \sigma_{P S I I}^{\prime}, \mathrm{nm}^{2}\right)$ were derived and averaged from 30 consecutive acquisitions with an interval of $120 \mathrm{~ms}$. Each of the acquisition was fitted with the KPF model (Kolber et al., 1998), with the help of FastPRO software (Chelsea Technologies Group). After measuring the FLCs, all the fluorescence values were adjusted by subtracting the fluorescence of the Whatman GF/F glass fiber-filtrated seawater to eliminate the influence of the blank (Cullen and Davis, 2003). We calculated the photochemical PSII quantum yields $\left(\mathrm{F}_{\mathrm{V}} / \mathrm{F}_{\mathrm{M}}, \frac{F_{q}}{F_{M}^{\prime}}\right)$ in the dark- and light-regulated state (Genty et al., 1989) as

$$
\frac{F_{V}}{F_{M}}=\frac{F_{M}-F_{O}}{F_{M}} ; \quad \frac{F_{q}}{F_{M}^{\prime}}=\frac{F_{M}^{\prime}-F}{F_{M}^{\prime}}
$$

After this, we derived the photosynthetic parameters, including the light utilization efficiency $(\alpha)$ and saturation irradiance $\left(\mathrm{E}_{\mathrm{K}}\right.$, $\mu \mathrm{mol}$ photons $\mathrm{m}^{-2} \mathrm{~s}^{-1}$ ) from the rapid light curve (RLC) as follows (Webb et al., 1974; Silsbe and Kromkamp, 2012):

$$
\frac{F_{q}}{F_{M}^{\prime}}=\alpha \times E_{K} \times\left(1-e^{\frac{-E}{E_{K}}}\right) \times E^{-1}
$$

where $\mathrm{E}$ denotes actinic light intensity (E, $\mu \mathrm{mol}$ photon $\left.\mathrm{m}^{-2} \mathrm{~s}^{-1}\right)$.

\section{Chlorophylla Measurement}

To measure the size-fractioned Chlorophylla (Chla) concentration in the surface and the DCM layers, 1-L seawater was sequentially filtrated through a $20-\mu \mathrm{m}$ pore-sized nylon-net filter ( $25 \mathrm{~mm}$, Millipore), a $3-\mu \mathrm{m}$ pore-sized polycarbonate filter (25 mm, Millipore), and $0.7-\mu \mathrm{m}$ pore-sized glass fiber filter (25 mm, Whatman GF/F). And, then, the filters were wrapped in aluminum foils, instantly stored at $-20^{\circ} \mathrm{C}$ until laboratorial analysis. After returning to the laboratory, the refrigerated filters with phytoplankton cells were extracted overnight in magnesium carbonate-saturated $90 \%$ acetone $(\mathrm{v} / \mathrm{v})$ at $4^{\circ} \mathrm{C}$; after centrifuging for $10 \mathrm{~min}$ at $3,500 \mathrm{rpm}$, the extraction was fluorescently measured with a Turner Designs 10 Fluorometer. Chla concentration was calculated, following Parsons et al. (1984). Total Chla concentration was obtained by summing all three size-fractioned Chla concentration. 


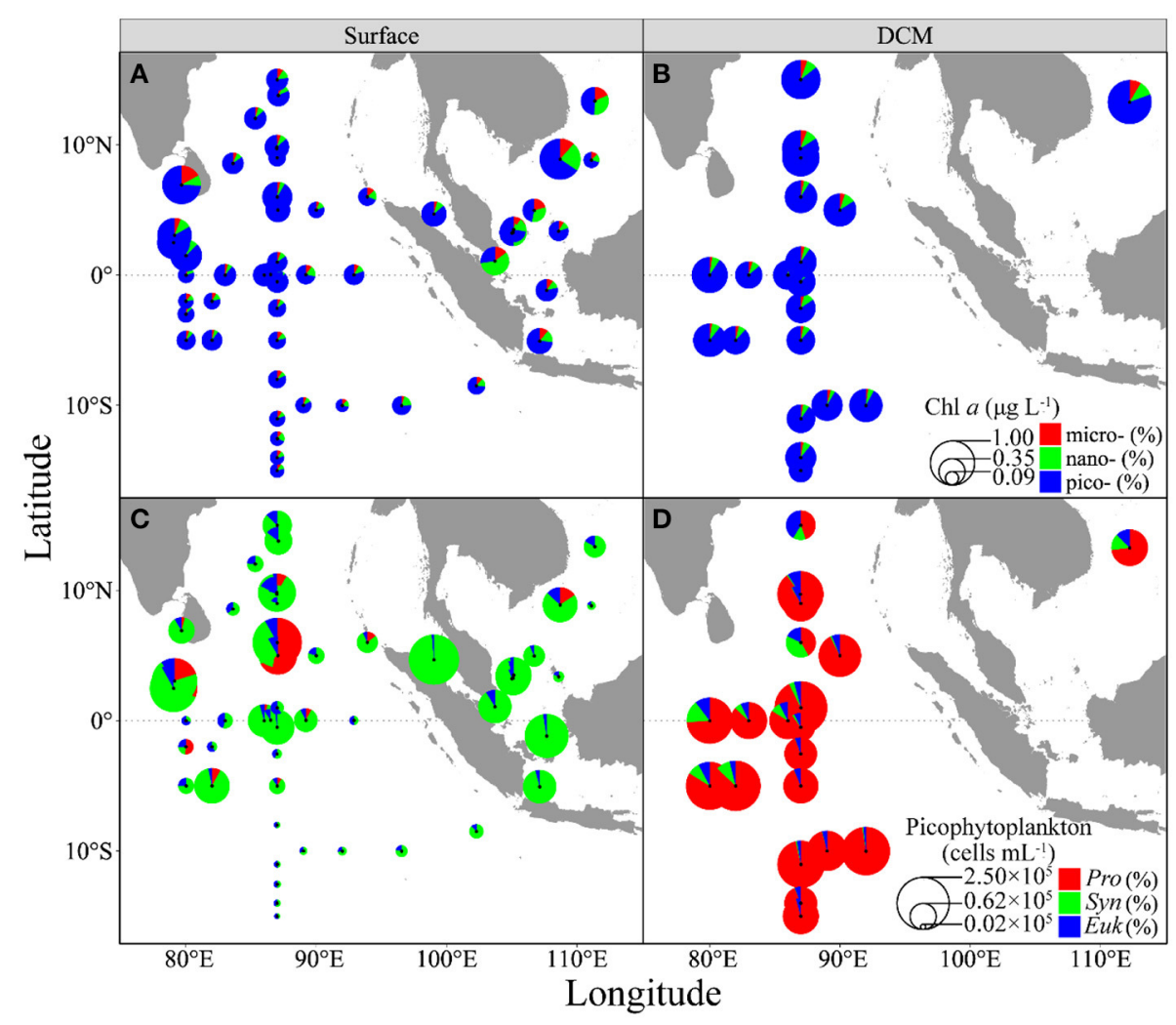

FIGURE 2 | Spatial distributions of three-size-fractioned chlorophyll a concentration (A,B, Chla, $\left.\mu \mathrm{gL}^{-1}\right)$ and picophytoplankton abundances $\left(\mathbf{C}, \mathbf{D}\right.$, cells $\left.\mathrm{m}^{-1}\right)$ in the surface $(\mathbf{A}, \mathbf{C})$ and DCM layers $(\mathbf{B}, \mathbf{D})$ throughout the surveyed areas. Pie-size shows Chla concentration or pico-cells abundance, whereas the colors show different fractions. micro-, micro-phytoplankton; nano-, nano-phytoplankton; pico-, pico-phytoplankton; Pro, Prochlorococcus; Syn, Synechococcus; and Euk,

pico-eukaryotes.

\section{Picophytoplankton Abundance Measurement}

To measure picophytoplankton abundance, the seawater from the surface and DCM layers was pre-filtrated through a 20 $\mu \mathrm{m}$ pore-sized nylon-net filter, dispensed into triplicate 2$\mathrm{mL}$ cryotubes and fixed with a final concentration of $0.5 \%$ glutaraldehyde $(\mathrm{v} / \mathrm{v})$. After shaken to make the samples being fully mixed, the cryotubes were kept in the dark for $20 \mathrm{~min}$, and then were flash frozen and stored in liquid nitrogen until later analysis. Cell abundance of Prochlorococcus (Pro), Synechococcus (Syn), and pico-eukaryotes (Euk) was measured with an Accuri C6 flow cytometry (Becton-Dickinson, USA), excited with blue argon $(488 \mathrm{~nm})$ and red diode lasers $(640 \mathrm{~nm})$. The samples were run at a medium-flow rate and collected $40 \mu \mathrm{L}$ for each measurement with the Accuri C6; and the data were then collected, saved, and analyzed with CellQUEST software.

\section{Statistical Analysis}

All the statistical analysis and figures were conducted, using $\mathrm{R}$ software (R Core Team, 2020), with packages of "ggOceanMaps" version 1.0.9 (Vihtakari, 2021), "ggplot2" (Wickham, 2016), "scatterpie" version 0.1.5 (Yu, 2020), and "rstatix" version 0.7.0 (Kassambara, 2021). To test the differences between the surface and DCM layers or among different geographical areas or temperature treatments, we firstly determined whether or not the measured parameters violate the normality and homogeneity of variance. If inviolate, the $\mathrm{t}$-test or one-way repeated measures ANOVA was used; otherwise, the Wilcoxon test or the Friedman test was used. The post hoc tests for one-way repeated measures ANOVA and the Friedman test were pairwise paired $t$-test and the Wilcoxon signed-rank test, respectively. Linear regression was also applied to test the correlation of photochemical parameters to temperature. The significance level was set at 0.05 .

\section{RESULTS}

During the investigated period, surface seawater temperature and salinity varied from 26.11 to $30.0^{\circ} \mathrm{C}$ (median, $29.10^{\circ} \mathrm{C}$ ) and from 29.58 to 35.59 (median, 34.32) throughout the surveyed areas, respectively (Supplementary Figure 1). Depth of DCM shoaled from 100 to $35 \mathrm{~m}$ from the southern to northern parts of the eastern Indian Ocean, with the temperature increased from 23.28 to $29.30^{\circ} \mathrm{C}$ (median, $27.90^{\circ} \mathrm{C}$ ); and the DCM depth was $59 \mathrm{~m}$ at the S2 station in the South China Sea, with the temperature of $25.80^{\circ} \mathrm{C}$. 


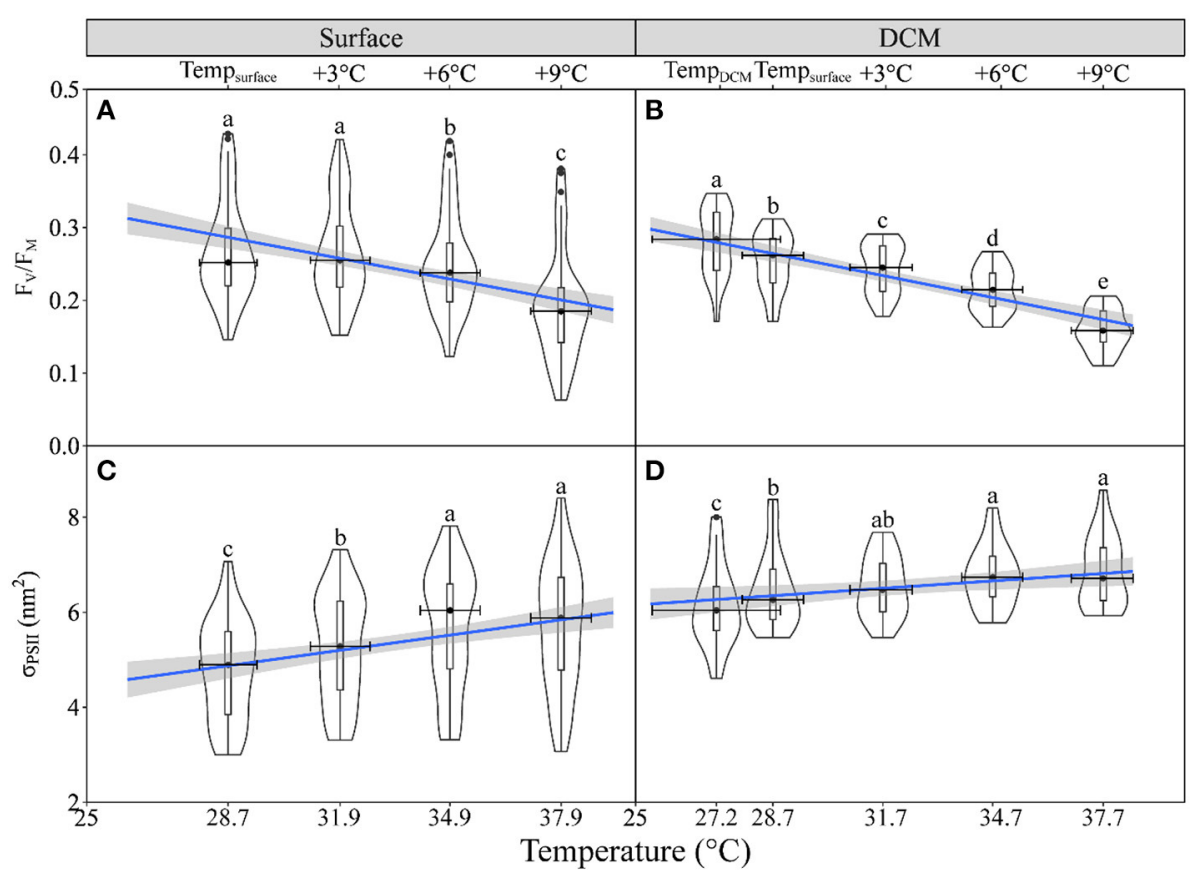

FIGURE 3 | The violin plot and the boxplot of maximum photochemical quantum yield (A,B, $\left.F_{V} / F_{M}\right)$ of photosystem II (PSII) and dark-adapted absorption cross-section of PSII photochemistry (C,D, $\left.\sigma_{P S I I}, n^{2}\right)$ against temperature for phytoplankton assemblages in the surface (A,C) and DCM layers (B,D). The blue line shows the linear regression of $F_{V} / F_{M}$ and $\sigma_{P S I}$ against temperature with shadow, indicating a 95\% confidence level, and horizontal bars indicate the standard deviations ( $n=47$ or 20). Different letters on top of each violin plot of each panel indicate significant differences between different temperature treatments. $(\mathbf{A}) \chi^{2}$ (3) $=$ $102.1, p<0.001$; (B) $F_{(1.67,26.74)}=120.1, p<0.001$; (C) $\chi_{(3)}^{2}=103.5, p<0.001$; (D) $\chi_{(4)}^{2}=30.6, p<0.001$.

Surface phytoplankton biomass (Chla) ranged from 0.09 to $0.86 \mu \mathrm{g} \mathrm{L}^{-1}$ throughout the surveyed areas, with a median of $0.22 \mu \mathrm{g} \mathrm{L}^{-1}$ (Figure 2A). Chla concentration was higher in the northern part of the surveyed areas than that in the southern part (Wilcoxon test, $p<0.001$ ). Chl $a$ in the DCM layer ranged from 0.29 to $0.99 \mu \mathrm{g} \mathrm{L}^{-1}$ (median, $0.50 \mu \mathrm{g} \mathrm{L}^{-1}$ ) (Figure 2B), being 1.5 to 6.0 times higher than the surface. Picophytoplankton cells $(0.7-3 \mu \mathrm{m})$ took up $79 \%$ (median) of total Chla (range, $27 \%$ to $91 \%$ ) in the surface layer and nano- and micro-cells took up 11 and 8\%; while, in the DCM layer, pico-cells took up $88 \%$ (range, 80 to $92 \%$ ), and nano- and micro-cells took up 8 and $4 \%$, respectively. Coinciding with $\mathrm{Chla}$, pico-cells density ranged from $3.20 \times 10^{3}$ to $2.31 \times 10^{5}$ cells $\mathrm{mL}^{-1}$ (median, $3.69 \times 10^{4}$ cells $\mathrm{mL}^{-1}$ ) in the surface (Figure $2 \mathrm{C}$ ), being higher in the northern than the southern parts of the surveyed areas (Wilcoxon test, $p<0.001$ ); while, in the DCM layer, their density ranged from $7.44 \times 10^{4}$ to $2.57 \times 10^{5}$ cells $\mathrm{mL}^{-1}$ (median, $1.26 \times 10^{5}$ cells $\mathrm{mL}^{-1}$ ) (Figure $2 \mathrm{D}$ ). Finally, picophytoplankton compositions were dominated by Synechococcus (median, 79\%; range, 22 to 98\%) in the surface, but by Prochlorococcus (median, 91\%; range, 42 to $98 \%$ ) in the DCM layer (Figures 2C,D). The pico-eukaryotes contributed to $<10 \%$ of pico-cells composition in both the surface and DCM layers.

To assess the general effect of acutely increased temperature on photophysiology of phytoplankton over the surveyed regions, the pooled $\mathrm{F}_{\mathrm{V}} / \mathrm{F}_{\mathrm{M}}$ and $\sigma_{\mathrm{PSII}}$ were plotted against temperature.
The $\mathrm{F}_{\mathrm{V}} / \mathrm{F}_{\mathrm{M}}$ decreased with increased temperature in both the surface and DCM layers (slope, $-0.009, p<0.001$ ), with no significant difference between these two layers $(p=0.97)$ (Supplementary Figure 2); while the $\sigma_{\text {PSII }}$ increased in both the surface (slope, 0.105, $p<0.001$ ) and DCM layers (slope, $0.041, p=0.03$ ) (Figure 3). The $F_{V} / F_{M}$ in the surface had a median value of 0.25 (range, 0.15 to 0.43 ), lower than that in the DCM layer (median, 0.29; range, 0.17 to 0.35$)(\mathrm{t}=2.28, p$ $=0.02)$ (Figures $4 \mathrm{~A}, \mathrm{~B})$. The slope of $\mathrm{F}_{\mathrm{V}} / \mathrm{F}_{\mathrm{M}}$ against temperature, an indicator of the temperature-caused effect, ranged spatially from -0.018 to -0.001 (Figures 4C,D), with an insignificant difference between the surface and DCM layers. The $\sigma_{\text {PSII }}$ in the surface ranged from 3.00 to $7.07 \mathrm{~nm}^{2}$ (median, $4.90 \mathrm{~nm}^{2}$ ), lower than that in the DCM layer (range, 4.60 to 8.00; median, $6.04 \mathrm{~nm}^{2}$ ) (Figures 4E,F). At the same time, the $\sigma_{\text {PSII }}$ in both the surface and the DCM, was higher in the southern than the northern parts of the surveyed areas (Wilcoxon test, $p<0.05$ ), and the acutely increasing temperature-caused promotion (i.e., the slope) on $\sigma_{\text {PSII }}$ was higher in the surface than the DCM layer (Wilcoxon test, $p<0.01$ ) (Figures 4G,H).

Acutely rising temperature also reduced the rapid light curve (RLC)-derived light utilization efficiency $(\alpha)$ (slope, -0.014 , $p<0.001$ ) (Figure 5 and Supplementary Figure 2), with no significant difference between the surface and DCM layers $(\mathrm{t}=-0.98, p=0.33$, Figures 6C,D). Both the $\alpha$ (Figures 6A,B) and $\mathrm{E}_{\mathrm{K}}$ (Figures 6E,F) showed great variations throughout 


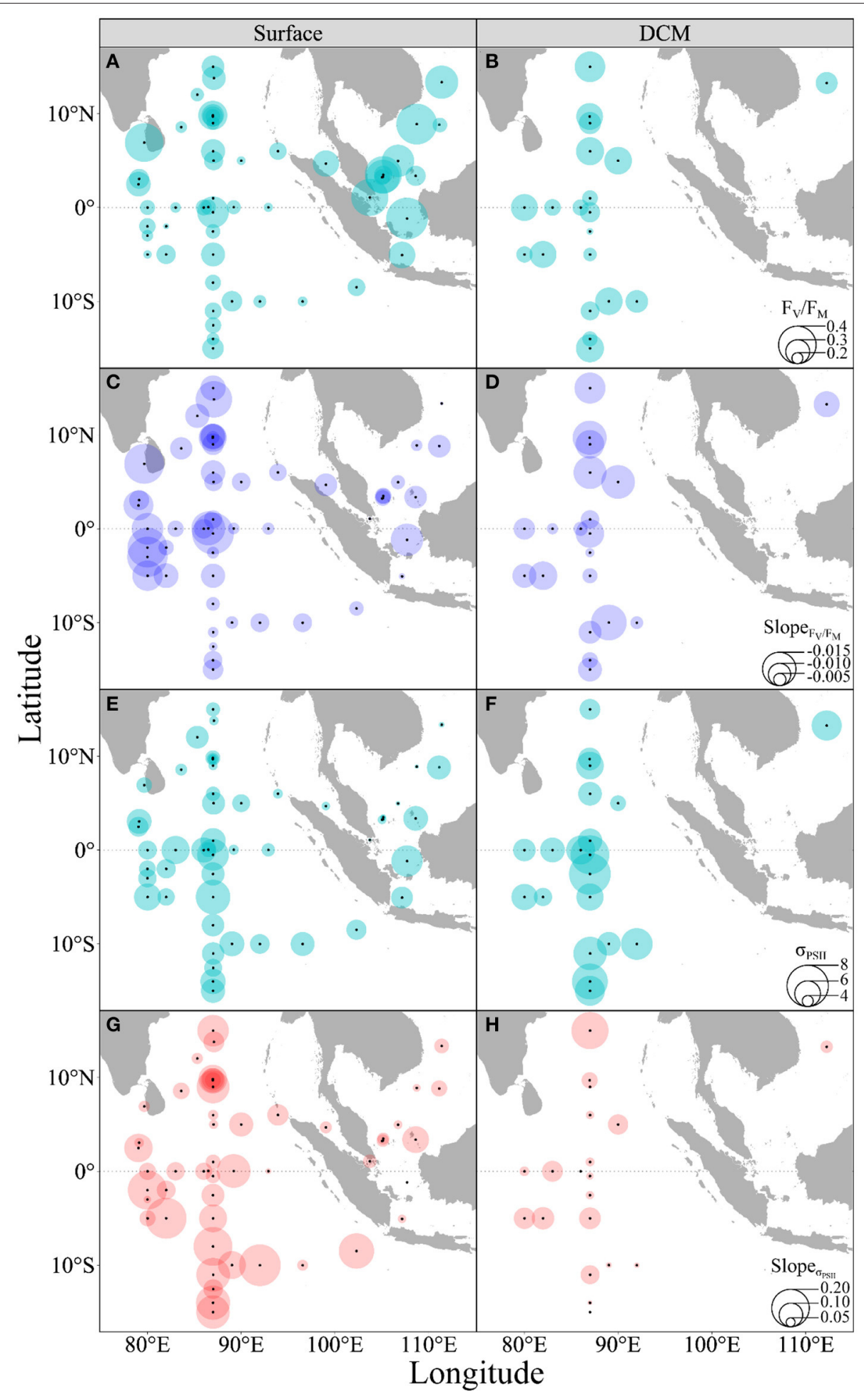

FIGURE 4 | Spatial distributions of maximal PS I| quantum yield (A,B, Fv/FM) and dark-adapted absorption cross-section (E,F, opsII, nm²), as well as the rising temperature-induced effects (slope) on $F_{V} / F_{M}(\mathbf{C}, \mathbf{D})$ and $\sigma_{P S I I}(\mathbf{G}, \mathbf{H})$ of phytoplankton assemblages in the surface $(\mathbf{A}, \mathbf{C}, \mathbf{E}, \mathbf{G})$ and $D C M$ layers $(\mathbf{B}, \mathbf{D}, \mathbf{F}, \mathbf{H})$ throughout the surveyed areas. Bubble size indicates the corresponding value. 


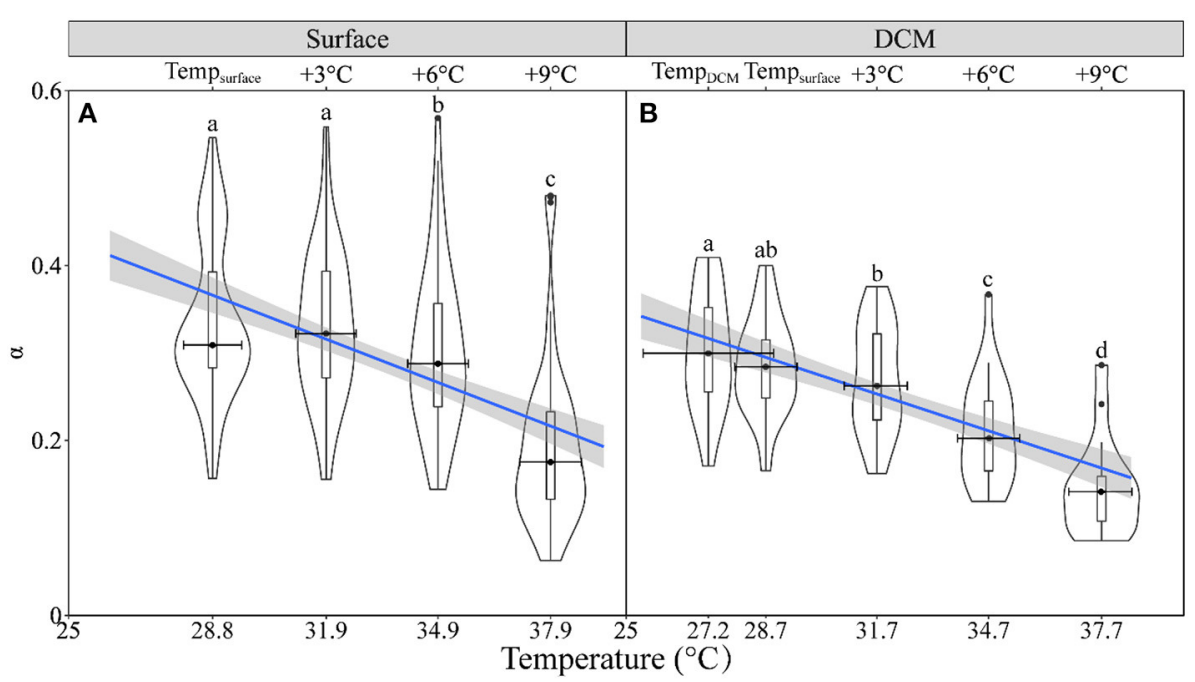

FIGURE 5 | The violin plot and the boxplot of the rapid light curve (RLC)-derived light utilization efficiency $(\alpha)$ against temperature for phytoplankton assemblages in the surface (A) and DCM layers (B). The blue line shows the linear regression of the $\alpha$ against temperature with shadow, indicating a $95 \%$ confidence level, and horizontal bars indicate the standard deviations $(n=47$ or 20). Different letters on top of each violin plot of each panel indicate significant differences between different temperature treatments. (A) $\chi_{(3)}^{2}=94.6, p<0.001$; (B) $F_{(2.32,37.15)}=72.26, p<0.001$

the surveyed areas. Moreover, the rising temperature-caused reduction did not occur in the RLC-derived saturation irradiance $\left(E_{K}\right)$ (Supplementary Figure 3). Finally, the higher $\alpha$ but lower $\mathrm{E}_{\mathrm{K}}$ prevailed in the DCM layer as compared with the surface layer, indicating the low-light acclimation of phytoplankton assemblages therein.

\section{DISCUSSION}

Model studies, together with field investigations, predicted that global warming would decrease marine primary production through dampening the nutrients up-transport from deep sea (Ruardij et al., 1997; Strom and Fredrickson, 2008; Roxy et al., 2016). In this study, we showed that the acutely increased temperature reduced the maximum photochemical efficiency $\left(\mathrm{F}_{\mathrm{V}} / \mathrm{F}_{\mathrm{M}}\right)$ and light utilization efficiency $(\alpha)$ of PSII of natural phytoplankton assemblages from both the surface and DCM layers in tropical oceans, thus providing physiological evidence for the adverse effect of rising temperature on the primary productivity. Moreover, we found both the $\mathrm{F}_{\mathrm{V}} / \mathrm{F}_{\mathrm{M}}$ and $\sigma_{\mathrm{PSII}}$ showed similar spatial variations throughout the surveyed regions, and the larger $\sigma_{\mathrm{PSII}}$, the higher $\alpha$, and the lower $\mathrm{E}_{\mathrm{K}}$ presented in the DCM than the surface layer, suggesting the lowlight acclimation of phytoplankton assemblages (Jin et al., 2016; Xie et al., 2018).

Chla biomass in the surface showed a markedly spatial variation, as well as pico-cells abundance (Figure 2). Generally, the growth and primary productivity of phytoplankton are regulated by macro- (e.g., nitrogen and phosphate) and/or micronutrients (e.g., dissolved iron) (Li et al., 2012a; Chinni et al.,
2019; Sherman et al., 2020). In the surveyed areas, the surface $\mathrm{N}$ and the P levels were $<1.0$ and $0.10 \mu \mathrm{M}$ (data not shown), with the N:P ratio being lower than 16 , indicating a nitrogen limitation ( $\mathrm{Li}$ et al., 2012a), especially in the southern Indian Ocean (Wilcoxon test, $p<0.05$ ), where Chla biomass and picocells abundance were lower. Such a biomass variation could also be attributed by the spatial changes of trace mental iron (Chinni et al., 2019; Twining et al., 2019) that is often believed to regulate phytoplankton growth and has been observed to covary with Chla (Chinni et al., 2019; Sherman et al., 2020). On the other hand, the spatial variation in Chla was less in the DCM layer; it could be explained by the high nutrients that may be enough to support the growth of phytoplankton. For phytoplankton compositions, pico- and nano-cells accounted for more than $90 \%$ of total Chla in both the surface and DCM layers, consistent with previous results (e.g., Li et al., 2012a,b). Moreover, Synechococcus dominated in the surface layer but Prochlorococcus dominated in the DCM layer, as found in this study (Figures 2C,D) or in others (Wei et al., 2019a; Mitbavkar et al., 2020). Different light harvesting complexes between Synechococcus and Prochlorococcus (phycobilisomes vs. divinyl-Chl $a / b$ antenna) and different cell sizes (ca. $0.9 \mu \mathrm{m} v s$. $0.6 \mu \mathrm{m}$ ) may make them adaptively prefer the light environments in surface and deep waters. Therefore, Prochlorococcus often has a lower light compensation point as compared with Synechococcus (Moore et al., 1995) and can more adaptively thrive and dominate in dim-deep waters. Moreover, the surface temperature in the surveyed areas was $\sim 29^{\circ} \mathrm{C}$ over the thermal-inhibited temperature of $25^{\circ} \mathrm{C}$ for the growth of Prochlorococcus (Moore et al., 1995), probably attributing to its less abundance in the surface layer (Wei et al., 2019a; Mitbavkar et al., 2020). 


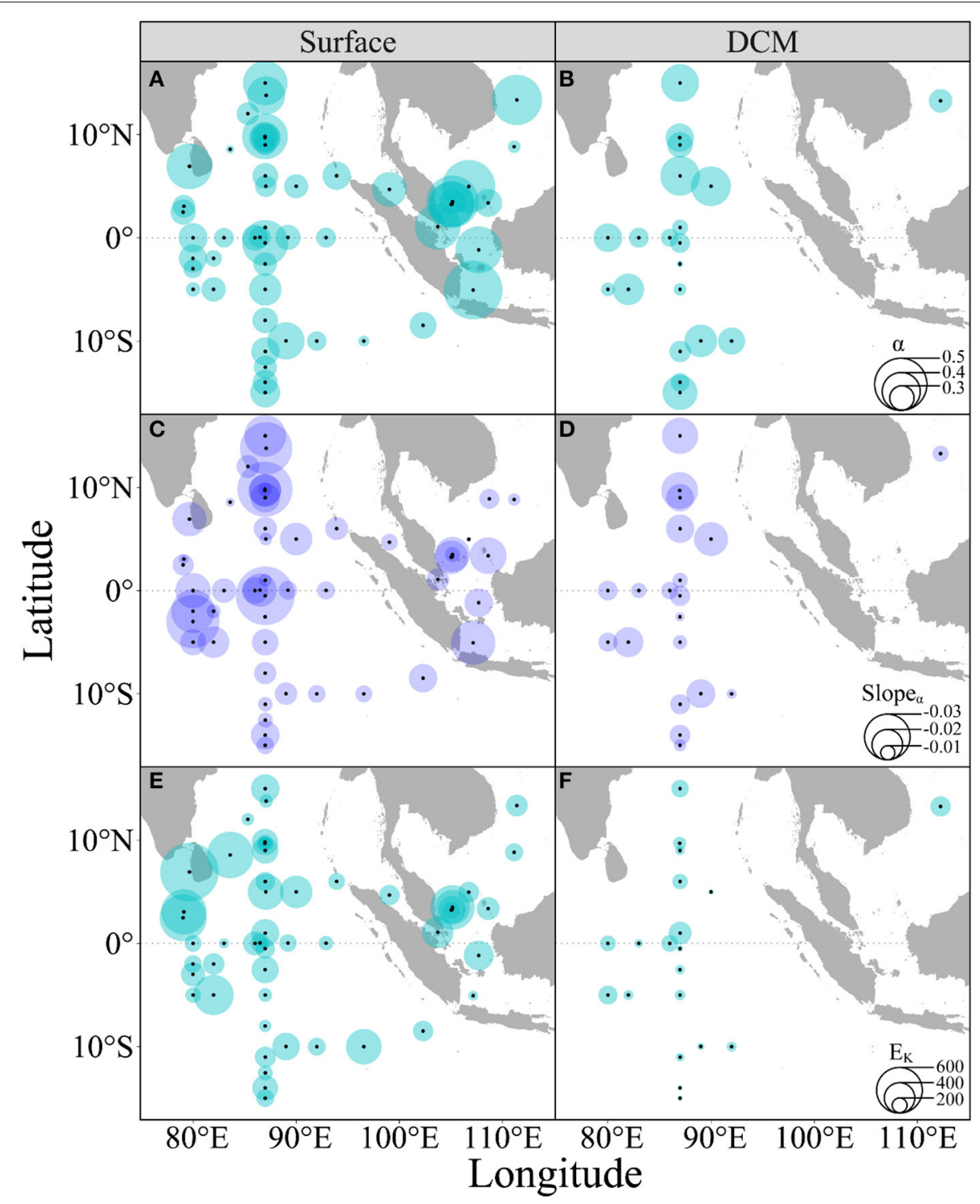

FIGURE 6 | Spatial distributions of the rapid light curve (RLC)-derived light utilization efficiency $(\mathbf{A}, \mathbf{B}, \alpha)$ and saturation irradiance $\left(\mathbf{E}, \mathbf{F}, E_{K}, \mu m o l\right.$ photons $\left.\mathrm{m}^{-2} \mathrm{~s}^{-1}\right)$, as well as the rising temperature-caused effects on $\alpha(\mathbf{C}, \mathbf{D})$ of phytoplankton assemblages in the surface $(\mathbf{A}, \mathbf{C}, \mathbf{E})$ and DCM layers $(\mathbf{B}, \mathbf{D}, \mathbf{F})$ throughout the surveyed areas. Bubble size indicates the corresponding value.

In addition, weak fluorescence in surface waters often makes Prochlorococcus hardly distinguishable by flow cytometry (Olson et al., 1990), which may also attribute to the lower measured cell counts.

The $\mathrm{F}_{\mathrm{V}} / \mathrm{F}_{\mathrm{M}}$ and $\alpha$, the indicators of photosynthetic status of phytoplankton, generally decline under unfavorable growth condition, presumably because of the damage of the PSII reaction center (Ragni et al., 2008; Suggett et al., 2009; Trimborn et al., 2015). The temperature in the surveyed areas usually maintains over $28^{\circ} \mathrm{C}$ throughout the year (De Deckker, 2016), which is close to or even over the optimal growth temperature of phytoplankton (Jin and Agustí, 2018). Reduction of further elevated temperature in photosynthetic capacity is thus predictable, although phytoplankton in the surface layer may have adaptively tolerated high temperature as indicated by the insignificant effect of initially acute $3^{\circ} \mathrm{C}$ increase (Figures $3 \mathbf{A}$, 5A). High temperature often makes cells generating excessive reactive oxygen species (ROS) (Anning et al., 2001; Deschaseaux et al., 2019) that is believed to unbalance the light absorption of photoautotrophs and utilization through inactivating the activities of photosynthetic enzymes, e.g., RubisCO, leading to a surplus accumulation of absorbed light energy, and, thus, the damage of photosynthetic apparatus and decrease of the $\mathrm{F}_{\mathrm{V}} / \mathrm{F}_{\mathrm{M}}$ and $\alpha$ (Anning et al., 2001; Deschaseaux et al., 2019). Meanwhile, the absorption cross-section of PSII photochemistry ( $\left.\sigma_{\text {PSII }}\right)$ increased with temperature in both the surface and DCM 
layers (Figures 3C,D). According to Suggett et al. (2009), many phytoplankton species can modulate the $\sigma_{\text {PSII }}$ to enable them to acclimate and adapt to varying light conditions; and the $\sigma_{\text {PSII }}$ can also be regulated by environmental variables, including temperature (Ni et al., 2017), cell size (Moore et al., 2005; Suggett et al., 2009), as well as nutrient status (Suggett et al., 2009). The increase of $\sigma_{\text {PSII }}$ with rising temperature can be explained by the "lake model" that assumes the energy absorbed by lightharvesting systems can transfer between photosynthetic units (Paillotin et al., 1983). If one functional PSII reaction center is inactivated or/and damaged due to, e.g., high temperature, its light-harvesting systems transfer the absorbed energy to neighboring active PS II, thus enlarging the $\sigma_{\text {PSII }}$. Although the long-term evolution may also enlarge the $\sigma_{\text {PSII }}$ to improve the light-absorbing ability to maintain photosynthesis (Suggett et al., 2009; Strzepek et al., 2012; Trimborn et al., 2015), it is not the case for minute-time-scaled measurements in this study. Moreover, the effects of increasing temperature on the $\sigma_{\text {PSII }}$, unlike on the $\mathrm{F}_{\mathrm{V}} / \mathrm{F}_{\mathrm{M}}$ or $\alpha$, were greater in the surface than the DCM layer. This could be attributed to different dominating species who have differential pigments compositions, because the pigments content, type, and arrangement inside the thylakoid membrane usually determine the size of the light-harvesting complex of PS II among phytoplankton groups (Suggett et al., 2009; Hughes et al., 2018b). Major pigments of Synechococcus to constitute the lightharvesting complexes are phycobilisomes (Sliwińska-Wilczewska et al., 2020), while that of Prochlorococcus are divinyl derivatives Chla/b (Ralf and Repeta, 1992); such a pigment difference may vary their light-harvesting abilities, thus leading to the differential photosynthetic responses to the acutely increased temperature between the surface and DCM layers. Larger $\sigma_{\text {PSI }}$ prevailed in the southern part of the surveyed areas where phytoplankton may have adaptively improved its light-harvesting abilities to sustain growth (Zhu et al., 2017; Sherman et al., 2020), because of the low nutrient status therein (data not shown). The larger $\sigma_{\text {PSII }}$ has also been suggested to be attributed to light-adapted genotypic feature due to niche partition (Jin et al., 2016), evidenced by the higher oPSII values of phytoplankton assemblages from deep waters.

In summary, we found that higher saturation irradiance $\left(\mathrm{E}_{\mathrm{K}}\right)$, together with lower Chla biomass, prevailed in the Synechococcus-dominated surface layer of the surveyed areas but being opposite in the Prochlorococcus-dominated DCM layer; and lower $\mathrm{F}_{\mathrm{V}} / \mathrm{F}_{\mathrm{M}}$ and $\alpha$ occurred in the former than the latter layers. Furthermore, we found the acutely rising temperature decreased the photosynthetic capacity (i.e., $\mathrm{F}_{\mathrm{V}} / \mathrm{F}_{\mathrm{M}}$ and $\alpha$ ) of

\section{REFERENCES}

Anning, T., Harris, G., and Geider, R. (2001). Thermal acclimation in the marine diatom Chaetoceroscalcitrans (Bacillariophyceae). Eur. J. Phycol. 36, 233-241. doi: 10.1080/09670260110001735388

Bouterfas, R., Belkoura, M., and Dauta, A. (2002). Light and temperature effects on the growth rate of three freshwater algae isolated from a eutrophic lake. Hydrobiologia 489, 207-217. doi: 10.1023/A:1023241006464

Buesseler, K. O., Boyd, P. W., Black, E. E., and Siegel, D. A. (2020). Metrics that matter for assessing the ocean biological carbon pump. natural phytoplankton assemblages from the surface and DCM layers of the eastern Indian Ocean, Java Sea, and southern South China Sea. Our results complement others (Roxy et al., 2016) to demonstrate that the ongoing global warming may adversely affect primary productivity in tropical oceans.

\section{DATA AVAILABILITY STATEMENT}

The original contributions presented in the study are included in the article/Supplementary Material, further inquiries can be directed to the corresponding author/s.

\section{AUTHOR CONTRIBUTIONS}

GM conducted the shipboard sampling and physiological measurements. GM, JL, XS, and GL designed the experiments and analyzed the data. GM, XP, and JL performed the pico-cells count determination. LY collected the temperature and salinity data. GM, JL, XS, BL, XX, YT, and GL wrote, discussed, and edited the paper. All authors contributed to the article and approved the submitted version.

\section{FUNDING}

This study was supported by National Key Research and Development Program of China (2019YFA0606704), National Natural Science Foundation (41890853), Key Special Project for Introduced Talents Team of Southern Marine Science and Engineering Guangdong Laboratory (Guangzhou) (GML2019ZD0407 and GML2019ZD0402), Special Foundation for National Science and Technology Basic Research Program of China (2018FY100104), National Natural Science Foundation (41676156), and Natural Science Foundation of Guangdong Province (2019B121202001). The data and the samples were collected onboard of R/V Shiyan 3, implementing the open research cruise NORC2020-10 supported by NSFC Shiptime Sharing Project (41949910), and we thank the crew for their help during the cruise.

\section{SUPPLEMENTARY MATERIAL}

The Supplementary Material for this article can be found online at: https://www.frontiersin.org/articles/10.3389/fmars. 2021.710697/full\#supplementary-material
Proc. Natl. Acad. Sci. U.S.A. 117, 9679-9687. doi: 10.1073/pnas.19181 14117

Cavicchioli, R., Ripple, W. J., Timmis, K. N., Azam, F., Bakken, L. R., Baylis, M., et al. (2019). Scientists' warning to humanity: microorganisms and climate change. Nat. Rev. Microbiol. 17, 569-586. doi: 10.1038/s41579-0190222-5

Chinni, V., Singh, S. K., Bhushan, R., Rengarajan, R., and Sarma, V. V. S. S. (2019). Spatial variability in dissolved iron concentrations in the marginal and open waters of the Indian Ocean. Mar. Chem. 208, 11-28. doi: 10.1016/j.marchem.2018.11.007 
Cullen, J. J., and Davis, R. F. (2003). The blank can make a big difference in oceanographic measurements. Limnol. Oceanogr. Bull. 12, 29-35. doi: $10.1002 /$ lob.200312229

De Deckker, P. (2016). The Indo-Pacific warm pool: critical to world oceanography and world climate. Geosci. Lett. 3:20. doi: 10.1186/s40562-016-0054-3

Deschaseaux, E., O’ Brien, J., Siboni, N., Petrou, K., and Seymour, J. R. (2019). Shifts in dimethylated sulfur concentrations and microbiome composition in the red-tide causing dinoflagellate Alexandriumminutum during a simulated marine heatwave. Biogeosciences 16, 4377-4391. doi: 10.5194/bg-16-4377-2019

Field, C. B., Behrenfeld, M. J., Randerson, J. T., and Falkowski, P. (1998). Primary production of the biosphere: integrating terrestrial and oceanic components. Science 281, 237-240. doi: 10.1126/science.281.5374.237

From, N., Richardson, K., Mousing, E. A., and Jensen, P. E. (2014). Removing the light history signal from normalized variable fluorescence $\left(\mathrm{F}_{\mathrm{V}} / \mathrm{F}_{\mathrm{M}}\right)$ measurements on marine phytoplankton. Limnol. Oceanogr. Meth. 12, 776-783. doi: 10.4319/lom.2014.12.776

Gao, K., Beardall, J., Häder, D.-P., Hall-Spencer, J. M., Gao, G., and Hutchins, D. A. (2019). Effects of ocean acidification on marine photosynthetic organisms under the concurrent influences of warming, UV radiation, and deoxygenation. Front. Mar. Sci. 6:322. doi: 10.3389/fmars.2019.00322

Gentemann, C. L., Fewings, M. R., and García-Reyes, M. (2017). Satellite sea surface temperatures along the West Coast of the United States during the 2014-2016 northeast Pacific marine heat wave. Geophys. Res. Lett. 44, 312-319. doi: 10.1002/2016GL071039

Genty, B., Briantais, J.-M., and Baker, N. R. (1989). The relationship between the quantum yield of photosynthetic electron transport and quenching of chlorophyll fluorescence. BBA Gen. Subjects 990, 87-92. doi: $10.1016 /$ S0304-4165(89)80016-9

Hobday, A. J., Alexander, L. V., Perkins, S. E., Smale, D. A., Straub, S. C., Oliver, E. C. J., et al. (2016). A hierarchical approach to defining marine heatwaves. Prog. Oceanogr. 141, 227-238. doi: 10.1016/j.pocean.2015.12.014

Hughes, D. J., Campbell, D. A., Doblin, M. A., Kromkamp, J. C., Lawrenz, E., Moore, C. M., et al. (2018b). Roadmaps and detours: active chlorophyll-a assessments of primary productivity across marine and freshwater systems. Environ. Sci. Technol. 52, 12039-12054. doi: 10.1021/acs.est.8b03488

Hughes, D. J., Varkey, D., Doblin, M. A., Ingleton, T., McInnes, A., Ralph, P. J., et al. (2018a). Impact of nitrogen availability upon the electron requirement for carbon fixation in Australian coastal phytoplankton communities. Limnol. Oceanogr. 63, 1891-1910. doi: 10.1002/lno.10814

IPCC (2013). "Summary for policymakers: climate change 2013 - the physical science basis," in Working Group 1 Contribution to the IPCC Fifth Assessment Report, eds T. F. S. T. G. Stocker, D. Qin, G.-K. Plattner, M. Tignor, S. K. Allen, J. Boschung, et al. (Cambridge: Cambridge University Press).

Jin, P., and Agustí, S. (2018). Fast adaptation of tropical diatoms to increased warming with trade-offs. Sci. Rep. 8:17771. doi: 10.1038/s41598-018-36091-y

Jin, P., Gao, G., Liu, X., Li, F., Tong, S., Ding, J., et al. (2016). Contrasting photophysiological characteristics of phytoplankton assemblages in the northern South China Sea. PLoS ONE 11:e0153555. doi: 10.1371/journal.pone.0153555

Jin, P., Overmans, S., Duarte, C. M., Agustí, S., and Bates, A. (2019). Increasing temperature within thermal limits compensates negative ultraviolet- $\mathrm{B}$ radiation effects in terrestrial and aquatic organisms. Global Ecol. Biogeogr. 28, 1695-1711. doi: 10.1111/geb.12973

Kassambara, A. (2021). Rstatix: Pipe-Friendly Framework for Basic Statistical Tests, Version 0.7.0. https://cran.r-project.org/web/packages/rstatix/index.html (accessed April 20, 2021).

Kolber, Z. S., Prášil, O., and Falkowski, P. G. (1998). Measurements of variable chlorophyll fluorescence using fast repetition rate techniques: defining methodology and experimental protocols. BBA Bioenergetics 1367, 88-106. doi: 10.1016/S0005-2728(98)00135-2

Kosro, P. M., Peterson, W. T., Hickey, B. M., Shearman, R. K., and Pierce, S. D. (2006). Physical versus biological spring transition: 2005. Geophys. Res. Lett. 33:L22SL03. doi: 10.1029/2006GL027072

Kudela, R. M., Cochlan, W. P., Peterson, T. D., and Trick, C. G. (2006). Impacts on phytoplankton biomass and productivity in the Pacific Northwest during the warm ocean conditions of 2005. Geophys. Res. Lett. 33:L22SL06. doi: 10.1029/2006GL026772
Li, G., Huang, L., Liu, H., Ke, Z., Lin, Q., Ni, G., et al. (2012a). Latitudinal variability $\left(6^{\circ} \mathrm{S}-20^{\circ} \mathrm{N}\right)$ of early summer phytoplankton species compositions and sizefractioned productivity from Java Sea to South China Sea. Mar. Biol. Res. 8, 163-171. doi: 10.1080/17451000.2011.615323

Li, G., Ke, Z., Lin, Q., Ni, G., Shen, P., Liu, H., et al. (2012b). Longitudinal patterns of spring-intermonsoon phytoplankton biomass, species compositions and size structure in the Bay of Bengal. Acta Oceanol. Sin. 31, 121-128. doi: 10.1007/s13131-012-0198-8

Li, W. K. W., Smith, J. C., and Platt, T. (1984). Temperature response of photosynthetic capacity and carboxylase activity in Arctic marine phytoplankton. Mar. Ecol. Prog. Ser. 17, 237-243. doi: 10.3354/meps017237

Mitbavkar, S., Anil, A. C., Narale, D. D., Chitari, R., Rao, V. T., and Gopalakrishna, V. V. (2020). Environmental influence on the picophytoplankton community structure in the central and northern Bay of Bengal. Reg. Stud. Mar. Sci. 40:101528. doi: 10.1016/j.rsma.2020.101528

Montie, S., Thomsen, M. S., Rack, W., and Broady, P. A. (2020). Extreme summer marine heatwaves increase chlorophyll $a$ in the Southern Ocean. Antarct. Sci. 32, 508-509. doi: 10.1017/S0954102020000401

Moore, C. M., Lucas, M. I., Sanders, R., and Davidson, R. (2005). Basin-scale variability of phytoplankton bio-optical char-acteristics in relation to bloom state and community structure in the Northeast Atlantic. Deep Sea Res. 52, 401-419. doi: 10.1016/j.dsr.2004.09.003

Moore, L. R., Goericke, R., and Chisholm, S. W. (1995). Comparative physiology of Synechococcusand Prochlorococcus: influence of light and temperature on growth pigments fluorescence and absorptive properties. Mar. Ecol. Prog. Ser. 116, 259-275. doi: 10.3354/meps116259

Mousing, E. A., Ellegaard, M., and Richardson, K. (2014). Global patterns in phytoplankton community size structure-evidence for a direct temperature effect. Mar. Ecol. Prog. Ser. 497, 25-38. doi: 10.3354/meps10583

Ni, G., Murphy, C. D., Zimbalatti, G., Barnett, A. B., Arsenault, C. M., Li, G., et al. (2017). Arctic Micromonas uses protein pools and non-photochemical quenching to cope with temperature restrictions on Photosystem II protein turnover. Photosynth. Res. 131, 203-220. doi: 10.1007/s11120-016$0310-6$

Oliver, E. C. J., Donat, M. G., Burrows, M. T., Moore, P. J., Smale, D. A., Alexander, L. V., et al. (2018). Longer and more frequent marine heatwaves over the past century. Nat. Commun. 9:1324. doi: 10.1038/s41467-018-03732-9

Olson, R. J., Chisholm, S. W., Zettler, E. R., Altabet, M. A., and Dusenberry, L. A. (1990). Spatial and temporal distributions of prochlorophyte picoplankton in the North Atlantic Ocean. Deep Sea Res. Pt A 37, 1033-1051. doi: 10.1016/0198-0149(90)90109-9

Pachiappan, P., Santhanam, P., Begum, A., and Balaji Prasath, B. (2019). Basic and Applied Phytoplankton Biology. Singapore: Springer.

Paillotin, G., Geacintov, N. E., and Breton, J. (1983). A master equation theory of fluorescence induction, photochemical yield, and singlet-triplet exciton quenching in photosynthetic systems. Biophys. J. 44, 65-77. doi: 10.1016/S0006-3495(83)84278-7

Parsons, T. R., Maita, Y., and Lalli, C. M. (1984). A Manual of Chemical and Biological Methods for Seawater Analysis. Amsterdam: Pergamon Press.

R Core Team (2020). R: A Language and Environment for Statistical Computing. R Foundation for Statistical Computing, Vienna. Available online at: https://www. R-project.org/ (accessed April 20, 2021).

Ragni, M., Airs, R. L., Leonardos, N., and Geider, R. J. (2008). Photoinhibition of PSII in Emiliania Huxleyi (Haptophyta) under high light stress: the roles of photoacclimation, photoprotection, and photorepair. J. Phycol. 44, 670-683. doi: $10.1111 / j .1529-8817.2008 .00524 . x$

Ralf, G., and Repeta, D. J. (1992). The pigments of Prochlorococcus marinus: the presence of divinylchlorophyll $a$ and $b$ in a marine procaryote. Limnol. Oceanogr. 37, 425-433. doi: 10.4319/lo.1992.37.2.0425

Roberts, S. D., van Ruth, P., Wilkinson, C., Bastianello, S. B., and Bansemer, M. S. (2019). Marine heatwave, harmful algae blooms and an extensive fish kill event during 2013 in South Australia. Front. Mar. Sci. 6:610. doi: 10.3389/fmars.2019.00610

Roxy, M. K., Modi, A., Murtugudde, R., Valsala, V., Panickal, S., Prasanna Kumar, S., et al. (2016). A reduction in marine primary productivity driven by rapid warming over the tropical Indian Ocean. Geophys. Res. Lett. 43, 826-833. doi: 10.1002/2015GL066979 
Ruardij, P., Van Haren, H., and Ridderinkhof, H. (1997). The impact of thermal stratification on phytoplankton and nutrient dynamics in shelf seas: a model study. J. Sea Res. 38, 311-331. doi: 10.1016/S1385-1101(97)00042-7

Schlüter, L., Lohbeck, K. T., Gutowska, M. A., Gröger, J. P., Riebesell, U., and Reusch, T. B. H. (2014). Adaptation of a globally important coccolithophore to ocean warming and acidification. Nat. Clim. Change 4, 1024-1030. doi: $10.1038 /$ nclimate2379

Sherman, J., Gorbunov, M. Y., Schofield, O., and Falkowski, P. G. (2020). Photosynthetic energy conversion efficiency in the West Antarctic Peninsula. Limnol. Oceanogr. 65, 2912-2925. doi: 10.1002/lno.11562

Silsbe, G. M., and Kromkamp, J. C. (2012). Modeling the irradiance dependency of the quantum efficiency of photosynthesis. Limnol. Oceanogr. Meth. 10, 645-652. doi: 10.4319/lom.2012.10.645

Sliwińska-Wilczewska, S., Konarzewska, Z., Wiśniewska, K., and Konik, M. (2020). Photosynthetic pigments changes of three phenotypes of picocyanobacteria Synechococcus sp. under different light and temperature conditions. Cells 9:2030. doi: $10.3390 /$ cells 9092030

Song, X., Tan, M., Xu, G., Su, X., Liu, J., Ni, G., et al. (2019). Is phosphorus a limiting factor to regulate the growth of phytoplankton in Daya Bay, northern South China Sea: a mesocosm experiment. Ecotoxicology 28, 559-568. doi: 10.1007/s10646-019-02049-7

Strom, S. L., and Fredrickson, K. A. (2008). Intense stratification leads to phytoplankton nutrient limitation and reduced microzooplankton grazing in the southeastern Bering Sea. Deep Sea Res. PT II 55, 1761-1774. doi: $10.1016 /$ j.dsr2.2008.04.008

Strzepek, R. F., Hunter, K. A., Frew, R. D., Harrison, P. J., and Boyd, P. W. (2012). Iron-light interactions differ in Southern Ocean phytoplankton. Limnol. Oceanogr. 57, 1182-1200. doi: 10.4319/lo.2012.57.4.1182

Suggett, D. J., Moore, C. M., Hickman, A. E., and Geider, R. J. (2009). Interpretation of fast repetition rate (FRR) fluorescence: signatures of phytoplankton community structure versus physiological state. Mar. Ecol. Prog. Ser. 376, 1-19. doi: $10.3354 /$ meps 07830

Thomsen, M. S., Mondardini, L., Alestra, T., Gerrity, S., Tait, L., South, P. M., et al. (2019). Local extinction of bull kelp (Durvillaea spp.) due to a marine heatwave. Front. Mar. Sci. 6:84. doi: 10.3389/fmars.2019.00084

Tokarska, K. B., Stolpe, M. B., Sippel, S., Fischer, E. M., Smith, C. J., Lehner, F., et al. (2020). Past warming trend constrains future warming in CMIP6 models. Sci. Adv. 6:eaaz9549. doi: 10.1126/sciadv.aaz9549

Trainer, V. L., Kudela, R. M., Hunter, M. V., Adams, N. G., and McCabe, R. M. (2020). Climate extreme seeds a new domoic acid hotspot on the US West Coast. Front. Clim. 2:571836. doi: 10.3389/fclim.2020.571836

Trimborn, S., Hoppe, C. J. M., Taylor, B. B., Bracher, A., and Hassler, C. (2015). Physiological characteristics of open ocean and coastal phytoplankton communities of Western Antarctic Peninsula and Drake Passage waters. Deep Sea Res. PT I 98, 115-124. doi: 10.1016/j.dsr.2014.12.010

Twining, B. S., Rauschenberg, S., Baer, S. E., Lomas, M. W., Martiny, A. C., and Antipova, O. (2019). A nutrient limitation mosaic in the eastern tropical Indian Ocean. Deep Sea Res. PT I 166, 125-140. doi: 10.1016/j.dsr2.2019.05.001

Vihtakari, M. (2021). GgOceanMaps: Plot Data on Oceanographic Maps Using 'ggplot2', Version 1.0.9. Available online at: https://cran.r-project.org/web/ packages/ggOceanMaps/index.html (accessed April 20, 2021). von Schuckmann, K., Cheng, L., Palmer, M. D., Hansen, J., Tassone, C., Aich, V., et al. (2020). Heat stored in the Earth system: where does the energy go? Earth Syst. Sci. Data 12, 2013-2041. doi: 10.5194/essd-12-20 13-2020

Webb, W. L., Newton, M., and Starr, D. (1974). Carbon dioxide exchange of Alnus rubra. Oecologia 17, 281-291. doi: 10.1007/BF00345747

Wei, Y., Zhang, G., Chen, J., Wang, J., Ding, C., Zhang, X., et al. (2019a). Dynamic responses of picophytoplankton to physicochemical variation in the eastern Indian Ocean. Ecol. Evol. 9, 5003-5017. doi: 10.1002/ece 3.5107

Wei, Y., Zhao, X., Sun, J., and Liu, H. (2019b). Fast repetition rate fluorometry (FRRf) derived phytoplankton primary productivity in the Bay of Bengal. Front. Microbiol. 10:1164. doi: 10.3389/fmicb.2019. 01164

Weller, E., Min, S.-K., Cai, W., Zwiers, F. W., Kim, Y.-H., and Lee, D. (2016). Human-caused Indo-Pacific warm pool expansion. Sci. Adv. 2:e1501719. doi: 10.1126/sciadv.1501719

Wickham, H. (2016). Ggplot2: Elegant Graphics for Data Analysis. New York, NY: Springer.

Xie, Y., Laws, E. A., Yang, L., Li, Q.-P., and Huang, B. (2018). Diel patterns of variable fluorescence and carbon fixation of picocyanobacteria Prochlorococcus-dominated phytoplankton in the South China Sea basin. Front. Microbiol. 9:1589. doi: 10.3389/fmicb.2018. 01589

Young, J. N., Goldman, J. A. L., Kranz, S. A., Tortell, P. D., and Morel, F. M. M. (2015). Slow carboxylation of Rubisco constrains the rate of carbon fixation during Antarctic phytoplankton blooms. New Phytol. 205, 172-181. doi: 10.1111/nph.13021

Yu, G. (2020). Scatterpie: Scatter Pie Plot, Version 0.1.6. Available online at: https://cran.r-project.org/web/packages/scatterpie/index.html (accessed April 20, 2021).

Zhang, Y., Wang, T., Li, H., Bao, N., Hall-Spencer, J. M., and Gao, K. (2018). Rising levels of temperature and $\mathrm{CO}_{2}$ antagonistically affect phytoplankton primary productivity in the South China Sea. Mar. Environ. Res. 141, 159-166. doi: 10.1016/j.marenvres.2018.08.011

Zhu, Y., Ishizaka, J., Tripathy, S. C., Wang, S., Sukigara, C., Goes, J., et al. (2017). Relationship between light, community composition and the electron requirement for C-fixation in natural phytoplankton. Mar. Ecol. Prog. Ser. 580, 83-100. doi: 10.3354/meps12310

Conflict of Interest: The authors declare that the research was conducted in the absence of any commercial or financial relationships that could be construed as a potential conflict of interest.

Copyright (c) 2021 Mai, Liu, Xia, Pang, Li, Yu, Tan, Song and Li. This is an openaccess article distributed under the terms of the Creative Commons Attribution License (CC BY). The use, distribution or reproduction in other forums is permitted, provided the original author(s) and the copyright owner(s) are credited and that the original publication in this journal is cited, in accordance with accepted academic practice. No use, distribution or reproduction is permitted which does not comply with these terms. 